\title{
Studi kerapatan mangrove dan perubahan garis pantai tahun 1989-2018 di Pesisir Provinsi Jambi
}

\author{
The study of mangrove density and shoreline changes from 1989 to 2018 in Jambi Province \\ Coastal Zone
}

Eva Achmad, Nursanti, Marwoto, Fazriyas, Dwi P. Jayanti

Program Studi Kehutanan, Fakultas Kehutanan, Universitas Jambi, Kampus Unja Pinang Masak, Jambi, Indonesia

\section{Article Info:}

Received: 15 - 02 - 2019

Accepted: 13 - $04-2020$

\section{Keywords:}

Abrasion, landsat images, mangrove, mangrove density, shorelines

\section{Corresponding Author:}

Eva Achmad

Program Studi Kehutanan,

Fakultas Kehutanan, Universitas Jambi;

Tel. +62251-8621262, 8621085

Email:

evaachmad@unja.ac.id

\begin{abstract}
The density of mangrove cover is one of the factors that influence changes in shoreline both accretion and abrasion. This study aims to determine the effect of changes in density of mangrove cover on shoreline changes in 1989-2018 in the coastal zone of Jambi Province. The method used was the interpretation of Landsat satellite images in 1989, 2000 and 2018 using NDVI (Normalized Difference Vegetation Index) and overlaying images to see shoreline changes and DSAS (Digital Shoreline Analysis System) to calculate the area of change. The results showed that there had been a change in shoreline both accretion and abrasion in several locations that had different mangrove densities in the period of 1989-2018. Moreover, accretion occured in 6 locations with an average change of Kota Sebrang $771 \mathrm{~m}$, Tungkal Ilir 240.65 m, Kuala Betara 153.73 m, Mendahara 167.78 m, Kuala Jambi $169.35 \mathrm{~m}$ and Nipah $57.3 \mathrm{~m}$, while abrasion occurred at 2 locations with an average change in Sabak Timur $-41.8 \mathrm{~m}$ and Sadu $-36.55 \mathrm{~m}$ respectively. Where in 6 locations that had accretion, mangrove density dominantly was in a close-densed and moderate state and only a few are in a low-densed condition. Meanwhile, the 2 locations that had abrasion were in a moderate state and have a low-density mangrove forest.
\end{abstract}

How to cite (CSE Style ${ }^{\text {th }}$ Edition):

Achmad E, Nursanti, Marwoto, Fazriyas, Jayanti DP. 2020. Studi kerapatan mangrove dan perubahan garis pantai tahun 1989-2018 di Pesisir Provinsi Jambi. JPSL 10(2): 138-152. http://dx.doi.org/10.29244/jpsl.10.2.138-152.

\section{PENDAHULUAN}

Hutan mangrove didefinisikan sebagai suatu tipe hutan yang tumbuh di daerah pasang surut (terutama di pantai yang terlindung, laguna, muara sungai) yang tergenang pada saat pasang dan bebas dari genangan pada saat surut serta komunitas tumbuhannya toleran terhadap garam (Kusmana et al., 2009). Daerah ini memiliki ekosistem yang kompleks dan berfungsi sebagai zona penyangga stabilitas ekosistem vital lainnya di wilayah pesisir sehingga berdasarkan letaknya mangrove mempunyai fungsi ganda, baik sebagai pelindung maupun sebagai pendukung ekosistem lainnya.

Dampak yang terjadi akibat alih fungsi mangrove salah satunya adalah perubahan garis pantai. Bengen (2001) menjelaskan bahwa salah satu pertahanan terbaik untuk menjaga suatu kawasan dari proses abrasi adalah hutan mangrove. Penurunan tutupan mangrove dalam skala besar akan mengurangi fungsinya secara fisik sebagai penjaga kestabilan garis pantai, mencegah abrasi, penangkap lumpur dan sedimen (Salim, 2014). Kerapatan mangrove berkontribusi terhadap tingkat luasan akresi, distribusi sedimen dan tinggi elevasi 
permukaan (Kumara et al., 2010). Hutan mangrove yang rapat akan menyebabkan bertambahnya daratan sepanjang pantai (akresi), dan sebaliknya pada areal yang hutan mangrovenya hilang maka akan memicu terjadinya abrasi pantai. Dengan demikian, kedua kondisi ini menyebabkan berubahnya garis pantai pada jangka panjang pada suatu wilayah. Salah satu kawasan hutan mangrove yang mengalami kerusakan yaitu di Pantai Pesisir Provinsi Jambi. Panjang garis pantai di Provinsi Jambi mencapai $221 \mathrm{~km}$ yang sebagian besar ditumbuhi oleh tegakan mangrove yakni di Kabupaten Tanjung Jabung Barat dan Tanjung Jabung Timur. Berdasarkan data Balai Konservasi Sumber Daya Alam (BKSDA) Provinsi Jambi (2014), luas hutan mangrove di Provinsi Jambi yaitu 4126.60 ha dengan persentase tutupannya sekitar 82.90\% dan kerapatan pohon 1164 pohon/ha.

Hasil pantauan dari BKSDA (2014) kondisi penutupan lahan di Cagar Alam Hutan Bakau Pantai Timur (CAHBPT) Jambi yang masih baik 2268.39 ha dan sudah dialih fungsi lahan oleh masyarakat untuk perkebunan seluas 1584.57 ha. Selain itu berdasarkan data olahan Buku Status Lingkungan Hidup Daerah (SLHD) Provinsi Jambi (2015), tutupan vegetasi mangrove di CAHBPT pada tahun 2012 sebesar 98\% dan berkurang menjadi 83\% pada tahun 2014 sedangkan di Cagar Alam Sungai Betara tutupan vegetasi yang awalnya 95\% pada tahun 2012 kini berkurang menjadi 78\% pada tahun 2014.

Pemantauan kerapatan tutupan mangrove dan perubahan garis pantai dapat dilakukan dengan menggunakan data penginderaan jauh dari beberapa periode. Citra satelit dapat merekam kondisi pesisir secara berkala sehingga perubahan garis pantai akan terlihat jika menumpang tindihkan dua citra di waktu yang berbeda (van Heuvel dan Hillen, 1994).

Tujuan penelitian adalah untuk menganalisis perubahan kerapatan mangrove tahun 1989-2018 di pesisir Provinsi Jambi dan menganalisis perubahan garis pantai di pesisir Provinsi Jambi menggunakan citra Landsat. Hasil dari penelitian ini diharapkan dapat memberikan gambaran mengenai kondisi mangrove selama hampir tiga dasawarsa ini dan perubahan garis pantai yang terjadi di pesisir pantai Provinsi Jambi.

\section{METODE}

\section{Lokasi dan Waktu Penelitian}

Penelitian ini dilaksanakan dari bulan Juli sampai dengan September 2018 di pesisir pantai Provinsi Jambi, meliputi Kabupaten Tanjung Jabung Barat dan Tanjung Jabung Timur.

\section{Bahan dan Alat}

Bahan yang digunakan adalah Citra Landsat TM tahun perekaman 1989, 2000 dan Landsat 8 tahun perekaman 2018 path/row 125/61 dan 125/60. Alat yang digunakan adalah software pengolahan data spasial. Beberapa peralatan survei untuk pengambilan data lapangan seperti kompas, phi-band, dan GPS.

\section{Pengolahan Data Citra Landsat}

Pada tahap ini ada beberapa kegiatan yang dilakukan, yang pertama yaitu mengkompositkan citra satelit Landsat. Komposit citra adalah citra baru hasil penggabungan dari beberapa kanal (band) yang memiliki resolusi yang sama untuk mendapatkan warna merah (red), hijau (green) dan biru (blue) yang mampu menampilkan keunggulan dari kanal-kanal penyusunnya. Untuk Citra Landsat TM kanal yang digunakan yaitu 1, 2, 3, 4 dan 5 sedangkan Landsat 8 yaitu 1, 2, 3, 4, 5, 6, 7 dan 9. Mangrove di kawasan sepanjang pantai dapat terlihat jelas dari citra FCC (False Color Composite). Kombinasi tersebut masing-masing adalah band 4, 5, 3 untuk Landsat TM dan band 5, 6, 4 untuk Landsat 8, hutan mangrove terlihat dengan warna merah kegelapan. 
Tahap selanjutnya adalah koreksi geometrik citra. Koreksi geometri adalah suatu tahap dalam merektifikasi (pembetulan) dan restorasi (pemulihan) citra agar koordinat sesuai dengan koordinat geografis. Koreksi geometrik pada citra Landsat merupakan upaya memperbaiki kesalahan perekaman secara geometrik agar citra yang dihasilkan mempunyai sistem koordinat dan skala yang seragam. Dalam penelitian ini, citra yang digunakan di koreksi geometri nya mengubah proyeksi menjadi Universal transverse Mercator (UTM) datum WGS 1984 zona 48S.

Tahap pra-pengolahan akhir berupa mosaik citra, merupakan metode untuk menggabungkan dua scene citra yang saling berdekatan atau berhimpitan. Hal ini dilakukan karena satu scene citra tidak mencakup semua lokasi penelitian yang dibutuhkan, maka dilakukan penambahan satu scene citra. Pada penelitian ini, citra yang akan dimosaik yaitu citra path/row 124/61 dan 125/61.

\section{Analisis Kerapatan Mangrove}

Analisis kerapatan mangrove dilakukan dengan metode Normalized Difference Vegetation Index (NDVI). Menurut Putra et al. (2016) NDVI akan menghasilkan data mengenai tinggi rendahnya suatu kerapatan vegetasi. NDVI menggunakan band merah dan infra merah dekat atau near infra red (NIR) dalam penginderaan jauh untuk mengetahui indeks vegetasi dari satelit. Di Landsat TM menggunakan band 4 dan band 3, sedangkan Landsat 8 menggunakan band 5 dan band 4. Algoritma NDVI (Rouse et al., 1973) adalah sebagai berikut:

$$
N D V I=\frac{\text { Band } N I R-B \text { and } R}{\text { Band } N I R+B \text { and } R}
$$

Keterangan:

NDVI= Normalized Difference Vegetation Index

$N I R=$ Nilai reflektansi spektral pada band infra merah dekat

$\mathrm{R} \quad=$ Nilai reflektansi spektral pada band merah

Tingkat kerapatan mangrove dibagi menjadi 3 kelas dimana mangrove dikelompokkan dalam kategori mangrove jarang, mangrove sedang dan mangrove rapat (Departemen Kehutanan, 2005).

Tabel 1 Kriteria tingkat kerapatan mangrove NDVI.

\begin{tabular}{lcc}
\hline \multicolumn{1}{c}{ Kategori Mangrove } & Presentase Tutupan $(\%)$ & Nilai NDVI \\
\hline Mangrove jarang & $0-50$ & $-1.0 \leq 0.32$ \\
Mangrove sedang & $51-69$ & $0.33 \leq 0.42$ \\
Mangrove rapat & $70-100$ & $0.43 \leq 1.00$ \\
\hline
\end{tabular}

\section{Delineasi Garis Pantai}

Untuk dapat mengetahui batas garis pantai maka dilakukan delineasi pada citra satelit tahun 1989, 2000 dan 2018. Delinasi merupakan kegiatan menarik garis dari suatu titik ke titik lain atau bisa juga disebut dengan istilah digitasi. Teknik delineasi garis pantai yang digunakan pada penelitian ini menggunakan metode False Color Composite Red Green Blue (FCC RGB).

Metode FCC RGB merupakan penajaman dengan menggunakan warna dalam meningkatkan kontras atau kualitas citra dengan menggabungkan tiga warna primer yaitu merah, hijau dan biru (RGB). Pada landsat TM komposit citra yang digunakan yaitu 542 sedangkan pada citra Landsat 8 composit yang digunakan 531. Kanal ini digunakan karena ketiga kanal tersebut paling sesuai untuk mendeteksi perubahan garis pantai (Winarso et al., 2001). 


\section{Perhitungan Perubahan Garis Pantai}

Pengolahan ini dilakukan dengan perangkat lunak Digital Shoreline Analysis System (DSAS). Penentuan jarak perpindahan titik perubahan garis pantai menggunakan metode Single Transect (ST), (Thieler et al., 2009). Metode single transect dilakukan dengan cara membuat baseline menggunakan buffer tool dengan jarak $10 \mathrm{~m}$, selanjutnya garis-garis transek dibuat tegak lurus terhadap baseline ke arah laut (seaward) dengan jarak antar transek $30 \mathrm{~m}$ dan panjang transek $1500 \mathrm{~m}$. Garis pantai tahun 1989-2018 menjadi garis shorelines yang akan dihitung laju perubahan garis pantainya.

Analisis jarak perubahan tiap titik garis pantai menggunakan metode Net Shoreline Movement (NSM) yaitu dengan mengukur jarak perubahan garis pantai antara garis pantai tahun terlama dan garis pantai tahun terbaru. Panjang jarak titik perpotongan setiap transek yang mewakili perubahan garis pantai ditandai sebagai nilai positif (+) pada pantai yang mengalami akresi dan nilai negatif (-) pada pantai yang mengalami abrasi (Kasim, 2012). Selanjutnya, dilakukan perhitungan perubahan rata-rata setiap tahunnya menggunakan metode end point rate (EPR). Perhitungan metode EPR yaitu menghitung perubahan (meter/tahun) ditentukan dengan membagi jarak (meter) perpindahan suatu posisi garis pantaimenurut lamanya rentang waktu (tahun) (Kasim, 2012). Secara matematis metode EPR dapat diformulasikan sebagai berikut (Limber et al., 2007).

Keterangan:

$$
R s e=\frac{X o}{t}
$$

Rse = perubahan end point rate (meter/tahun)

Xo = ukuran jarak horizontal perubahan suatu titik garis pantai (meter)

$\mathrm{t} \quad=$ rentang waktu (tahun) posisi garis pantai tersebut.

\section{Tahap Kerja Lapangan}

\section{Kerapatan Mangrove}

Penentuan plot analisis vegetasi ditentukan dengan metode purposive sampling berdasarkan tingkat kerapatan mangrove yaitu jarang, sedang dan rapat yang berjumlah 60 plot. Menurut Onrizal (2008) ukuran plot tegakan yang digunakan saat analisis vegetasi hutan mangrove adalah sebagai berikut:

1. Petak contoh $10 \times 10 \mathrm{~m}$ untuk pohon berdiameter $>10 \mathrm{~cm}$ dengan tinggi $>1.5 \mathrm{~m}$.

2. Petak contoh $5 \times 5 \mathrm{~m}$ untuk anakan pohon (pancang) dengan diameter $<10 \mathrm{~cm}$ dengan tinggi $1.5 \mathrm{~cm}$.

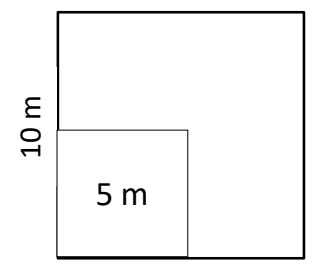

Gambar 1 Bentuk petak contoh.

Setelah data hasil analisis vegetasi diperoleh, kemudian dilakukan analisis data. Menurut Onrizal (2008) analisis data dapat dihitung menggunakan formula, yaitu:

$$
\text { Kerapatan }(\mathrm{K})=\frac{\text { Individu suatu jenis }}{\text { Luas Petak Contoh }}
$$

Analisis tingkat kerusakan mangrove mengacu kepada Keputusan Menteri Negara Lingkungan Hidup No. 201 Tahun 2004 tentang Kriteria Baku dan Pedoman Penentuan Kerapatan Mangrove. 
Tabel 2 Kriteria baku dan pedoman penentuan kerapatan mangrove.

\begin{tabular}{lcc}
\hline \multicolumn{1}{c}{ Kategori Mangrove } & Presentase Tutupan $(\%)$ & Kerapatan Pohon/ha \\
\hline Baik & $70-100$ & $\mathrm{x} \geq 1500$ \\
Sedang & $51-69$ & $1000 \leq \mathrm{x}<1500$ \\
Rusak & $0-50$ & $\mathrm{x}<1000$ \\
\hline
\end{tabular}

\section{Garis Pantai}

Tahap kerja lapangan garis pantai yaitu uji validasi, untuk mengetahui kondisi antara citra dengan kondisi sebenarnya. Hal ini dilakukan untuk membuktikan bahwa hasil pendefinisian antara daratan dan lautan yang telah dilakukan dalam penelitian dapat diterima (Istiqomah et al., 2016; Lubis et al., 2017). Tahap ini memanfaatkan transek-transek sebagai acuan dari pergerakan garis pantai. Transek untuk pengamatan dipilih sesuai jalur analisis vegetasi yang ditentukan yaitu berdasarkan tingkat kerapatan.

Pada transek yang telah dipilih diambil titik koordinatnya, sehingga saat di lapangan bisa dilakukan uji validasi terkait apakah benar telah menjadi daratan atau sudah bukan daratan. Dalam penelitian ini, uji validasi yang dilakukan menggunakan pasang surut terendah sementara. Data pasang surut terendah sementara tersebut didapatkan dari observasi dan wawancara kepada penduduk setempat (Parman, 2010).

\section{Validasi dan Akurasi Garis Pantai}

Berdasarkan hasil pengecekan titik sampel yang dilakukan di lapangan dengan bantuan Global Positioning System (GPS) nilai akurasi yang dianggap akurat yaitu yang mempunyai tingkat ketelitian $\geq 80 \%$. Menurut Short (1982) dan Estes dalam Harianto (2011), rumus untuk menentukan nilai akurasi adalah:

$$
\text { Ketelitian Keseluruhan }=\frac{\text { Jumlah titik yang benar di lapangan }}{\text { Jumlah seluruh titik yang diambil }} \times 100 \%
$$

\section{Hubungan Antara Kerapatan dan Perubahan Garis Pantai}

Untuk analisis hubungan antara kerapatan dan perubahan garis pantai menggunakan metode deskriptif. Metode deskriptif adalah penelitian yang dilakukan untuk mengetahui keberadaan variabel mandiri, baik hanya pada satu variabel atau lebih (variabel yang berdiri sendiri) tanpa membuat perbandingan dan mencari hubungan variabel itu dengan variabel yang lain (Sugiyono, 2005).

\section{HASIL DAN PEMBAHASAN}

\section{Kerapatan Tutupan Mangrove}

Berdasarkan analisis data citra satelit diperoleh hasil tingkat kerapatan vegetasi di daerah penelitian dari tingkat kerapatan jarang, sedang, dan rapat. Wilayah yang mempunyai vegetasi jarang ditunjukkan oleh warna merah (Gambar 2). Warna tersebut menunjukkan bahwa daerah tersebut mempunyai vegetasi yang sedikit dengan indeks kerapatan vegetasi -1 hingga 0.32 . Wilayah yang mempunyai vegetasi dengan tingkat kerapatan sedang ditunjukkan dengan warna kuning, dengan indeks kerapatan vegetasi berkiasar antara 0.32 hingga 0.42. Wilayah yang mempunyai tingkat kerapatan vegetasi rapat ditunjukkan dengan warna hijau, dengan indeks kerapatan berkisar antara 0.42 hingga 1. Tingkat kehijauan menunjukkan bahwa wilayah tersebut masih mempunyai vegetasi yang banyak, karena indeks vegetasi sendiri sebenarnya menggambarkan tingkat kehijauan tanaman).

Sebagian besar hutan mangrove di Provinsi Jambi pada Tahun 2018 berada pada tingkat kerapatan sedang. Dari interpretasi citra dapat dilihat bahwa di Kecamatan Mendahara (Mendahara Ilir), Kuala Jambi, Muara Sabak Timur (Simbur Naik) dan Sadu (Sungai Sambal, Sungai Sayang, Remaobakutuo) berada pada kelas 
kerapatan Rapat. Kecamatan Sebrang, Tungkal Ilir, Betara Sebagian Kecamatan Mendahara (Pangkal Duri dan Sungai Ayam), Nipah Panjang dan Sadu (Sungai Lokan) berada pada kelas kerapatan Sedang. Untuk kelas kerapatan Jarang, berada di Kecamatan Muaro Sabak Timur (Alang-Alang, Sungai Ular, Lambur) dan Sadu (Sungai Cemara).

\section{Perubahan Kerapatan Tutupan Mangrove}

Dari hasil interpretasi Citra Satelit tahun perekaman 1989, 2000 dan 2018 didapat hasil perubahan luasan kerapatan tutupan di Pesisir Provinsi Jambi pada Tabel 3.

Tabel 3 Perubahan luas tingkat kerapatan per kelas dari tahun 1989-2018.

\begin{tabular}{ccccc}
\hline \multirow{2}{*}{ Tahun } & \multicolumn{3}{c}{ Kerapatan (ha) } & \multirow{2}{*}{ Total (ha) } \\
\cline { 2 - 4 } & Jarang & Sedang & Tinggi & 8253.37 \\
1989 & 441.36 & 369.62 & 7442.39 & 6176.88 \\
2000 & 747.52 & 769.60 & 4659.75 & 10197.83 \\
2018 & 1155.83 & 5766.92 & 3275.08 & \\
\hline
\end{tabular}

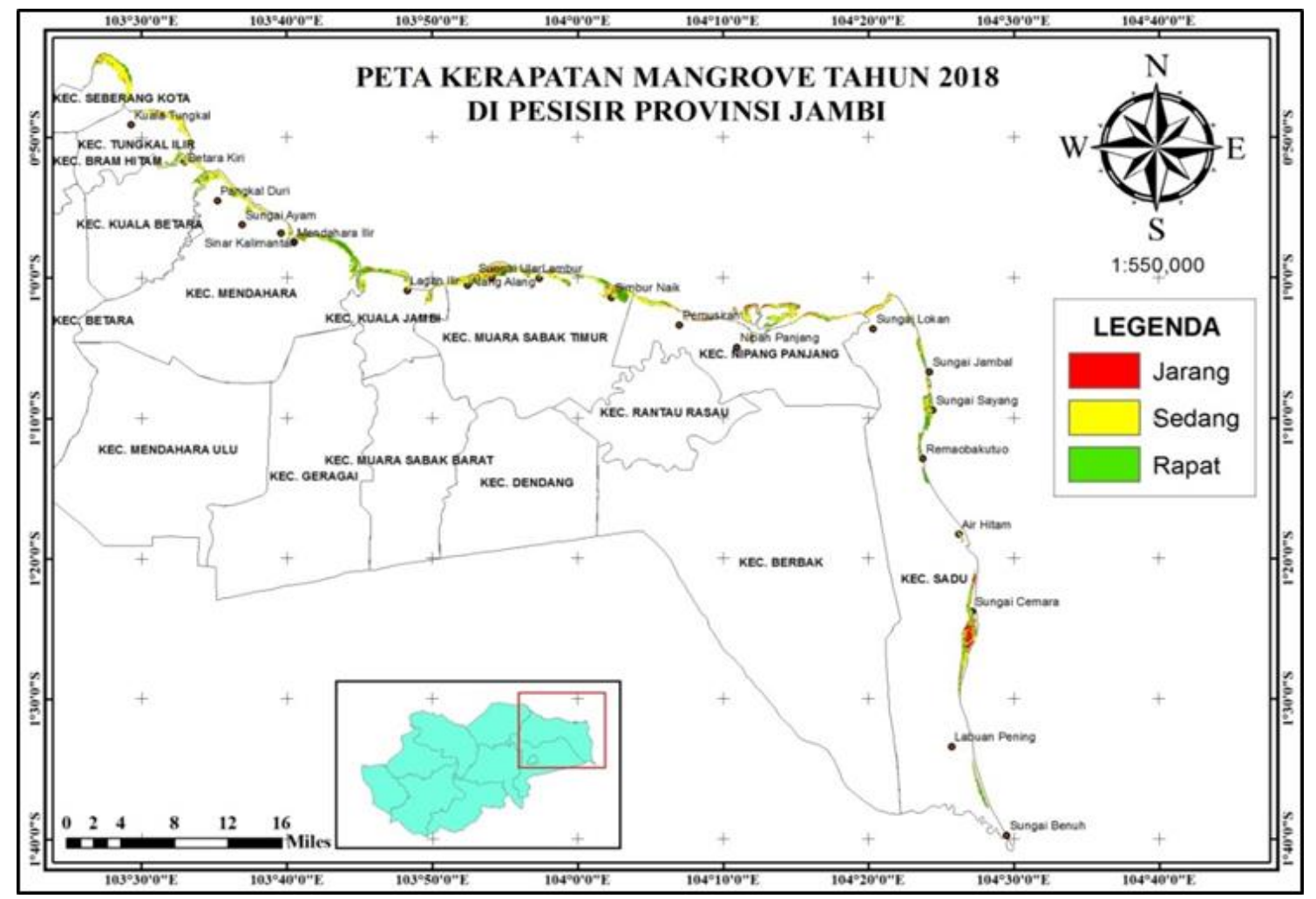

Gambar 2 Peta kerapatan mangrove.

Pengurangan untuk tingkat kerapatan tinggi terus menurun dari tahun ke tahun. Kerapatan tinggi ini berubah menjadi kerapatan sedang maupun jarang. Penyebab berkurangnya kerapatan hutan mangrove salah satunya karena semakin banyak masyarakat semakin banyak juga yang memanfaatkan hutan mangrove, baik dari segi lahan maupun kebutuhan akan manfaat dari spesies hutan mangrove itu sendiri. Hal ini terbukti dengan data yang dikeluarkan SLHD (2014), bahwa hutan mangrove pesisir Provinsi Jambi telah mengalami kerusakan karena adanya alih fungsi lahan menjadi perkebunan, serta eksploitasi yang dilakukan masyarakat untuk kepentingan ekonomi seperti penebangan kayu mangrove untuk kayu bakar, pembuatan arang hingga konstruksi beton. 
Pada tahun 1989, tutupan kerapatan mangrove didominasi oleh tutupan kerapatan tinggi walau ada di beberapa lokasi yang memiliki tutupan kerapatan rendah dan jarang, namun tidak terlalu signifikan. Kerapatan tutupan mangrove mulai terganggu pada tahun 2000, dimana hampir di seluruh Kecamatan yang berbatasan dengan pesisir Provinsi Jambi mengalami peningkatan untuk kategori tutupan sedang dan jarang. Pada tahun 2018, hampir semua kecamatan berada pada kategori dominan sedang dan ada dua kecamatan yaitu Sabak Timur dan Sadu yang memiliki luas kategori kerapatan jarang yang cukup besar (Tabel 4).

Tabel 4 Perubahan kerapatan tutupan mangrove di pesisir Provinsi Jambi.

\begin{tabular}{|c|c|c|c|c|c|}
\hline \multirow{2}{*}{ No } & \multirow{2}{*}{ Kecamatan } & \multirow{2}{*}{ Tahun } & \multicolumn{3}{|c|}{ Luas (ha) } \\
\hline & & & Jarang & Sedang & Rapat \\
\hline \multirow{4}{*}{1} & \multirow{4}{*}{ Kota Sebrang } & 2018 & 46.38 & 643.04 & 175.28 \\
\hline & & 2000 & 19.99 & 31.05 & 425.8 \\
\hline & & 1989 & 13.26 & 10.92 & 385.66 \\
\hline & & 2018 & 44.30 & 492.62 & 92.75 \\
\hline \multirow[t]{3}{*}{2} & \multirow[t]{3}{*}{ Tungkal Ilir } & 2000 & 79.73 & 52.94 & 265.76 \\
\hline & & 1989 & 24.36 & 15.28 & 484.25 \\
\hline & & 2018 & 15.18 & 151.16 & 57.51 \\
\hline \multirow[t]{3}{*}{3} & \multirow[t]{3}{*}{ Kuala Betara } & 2000 & 21.50 & 16.12 & 167.72 \\
\hline & & 1989 & 14.57 & 6.47 & 420.84 \\
\hline & & 2018 & 47.61 & 917.82 & 638.91 \\
\hline \multirow[t]{3}{*}{4} & \multirow[t]{3}{*}{ Mendahara } & 2000 & 105.09 & 174.17 & 873.15 \\
\hline & & 1989 & 34.12 & 45.19 & 1208.44 \\
\hline & & 2018 & 35.72 & 397.50 & 330.99 \\
\hline \multirow[t]{3}{*}{5} & \multirow[t]{3}{*}{ Kuala Jambi } & 2000 & 77.20 & 73.08 & 215.53 \\
\hline & & 1989 & 43.75 & 46.60 & 426.08 \\
\hline & & 2018 & 191.93 & 1178.87 & 649.49 \\
\hline \multirow[t]{3}{*}{6} & \multirow[t]{3}{*}{ Sabak Timur } & 2000 & 62.88 & 89.16 & 744.83 \\
\hline & & 1989 & 40.19 & 42.58 & 1542.02 \\
\hline & & 2018 & 123.62 & 499.49 & 186.79 \\
\hline \multirow[t]{3}{*}{7} & \multirow[t]{3}{*}{ Nipah Panjang } & 2000 & 125.06 & 137.73 & 419.13 \\
\hline & & 1989 & 38.92 & 67.51 & 1078.22 \\
\hline & & 2018 & 469.19 & 1015.03 & 944.72 \\
\hline \multirow[t]{2}{*}{8} & \multirow[t]{2}{*}{ Sadu } & 2000 & 126.33 & 106.44 & 1114.28 \\
\hline & & 1989 & 90.96 & 74.40 & 1605.8 \\
\hline
\end{tabular}

\section{Analisis Vegetasi di Lapangan}

Untuk analisis vegetasi di lapangan, dilakukan di 60 titik yang tersebar di sepanjang pesisir Provinsi Jambi yaitu di Hutan Mangrove Dusun Bahagia Pangkal Babu Kuala Tungkal, Hutan Mangrove Lambur Luar dan Hutan Mangrove Mendahara Ilir. Dari hasil analisis vegetasi ini, diperoleh bahwa antara nilai NDVI dan analisis vegetasi di lapangannya sebanyak 45 titik plot contoh yang sesuai atau sebesar $75 \%$.

Salah satu lokasi yang menjadi lokasi ground check yaitu di Kuala Tungkal atau lebih tepatnya di Dusun Bahagia Desa Pangkal Babu. Menurut kepala dusun dan warga masyarakat pengelola, pengelolaan hutan mangrove di sini masih sangat baik. Sering dilakukan penanaman mangrove dari berbagai instansi serta masyarakatnya juga peduli akan keberadaan mangrove sehingga tidak terjadi perambahan.

Dari interpretasi citra, didapatkan data bahwa hutan mangrove ini berada dalam tutupan kerapatan yang sedang, namun dari analisis vegetasi di lapangan kerapatan mangrovenya berada pada tingkat kerapatan tinggi atau rapat. Hasil dari analisis vegetasi menunjukkan bahwa kerapatan mangrove rata-rata Desa Pangkal Babu yaitu 1525 individu/ha berdasarkan kriteria kerapatan mangrove yang dikeluarkan oleh Departemen Kehutanan tahun 2005, termasuk kategori kerapatan yang rapat. 
Tabel 5 Nama spesies yang ditemukan di plot pengamatan pangkal babu.

\begin{tabular}{ccc}
\hline No & Nama Lokal & Nama Latin \\
\hline 1 & Bakau putih & Rhizophora apiculata \\
2 & Api-api hitam & Avicennia officinalis \\
3 & Lagadai & Bruguiera parviflora \\
4 & Bakau tanduk & Rhizophora stylosa \\
5 & Bakau putih & Rhizophora apiculata \\
6 & Perepat & Sonneratia alba \\
7 & Api-api kuning & Avicennia alba \\
8 & Pisang-pisang & Kandelia candel \\
\hline
\end{tabular}

Perbedaan antara data hasil interpretasi citra dan data hasil analisis di lapangan bisa saja terjadi karena adanya pengaruh pasang surut air laut pada saat waktu perekaman citra. Hal itu juga diperkuat dengan penelitian yang telah dilakukan sebelumnya oleh Ajithkumar et al. (2008) tentang karakteristik spektral mangrove yang tidak hanya dipengaruhi oleh kandungan klorofil saja tetapi juga dipengaruhi oleh kondisi lingkungan sekitarnya yaitu air dan tanah.

Formasi hutan mangrove ini didominasi oleh jenis Api-api (Avicennia sp) dan Bakau (Rhizophora sp), ini bukan formasi alami karena terbentuk akibat aktivitas penanaman bekas area tambak (Gambar 3). Untuk formasi yang masih baik berada di tepi aliran sungai, dimana pada urutan formasi tanaman dari yang terdepan adalah Api-api (Avicennia sp), kemudian Perepat (Sonneratia alba), Bakau (Rhizophora sp), Tancang (Bruguiera sp), hingga sampai ke formasi terakhir yaitu Nipah (Nypa fruticans).

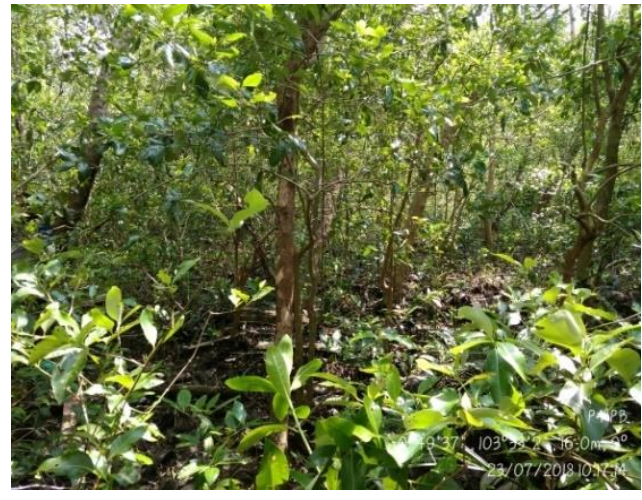

(a)

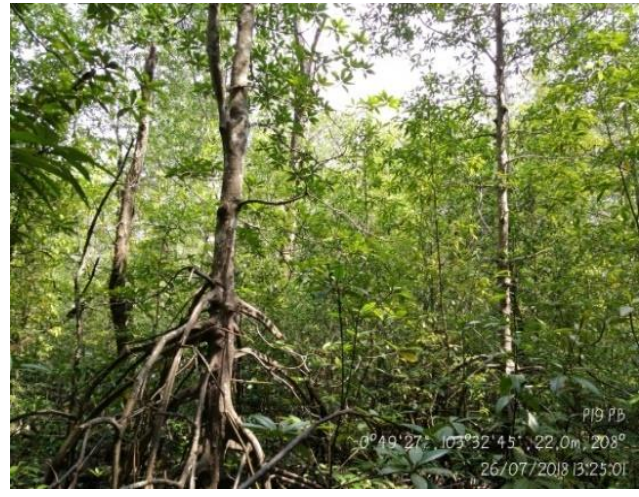

(b)

Gambar 3 Formasi hutan mangrove pangkal babu (a) Api-api (Avicennia sp) (b) Bakau (Rhizophora sp).

Untuk lokasi ground check selanjutnya yaitu di Desa Lambur Luar (Gambar 4). Saat dilakukan pengecekan lapangan, sebagian besar hutan mangrove telah menjadi lahan bekas tambak serta lahan yang baru saja dilakukan kegiatan penanaman. Tepat di belakang hutan mangrove yang sudah terkena abrasi ini, terdapat perkebunan kelapa masyarakat. 


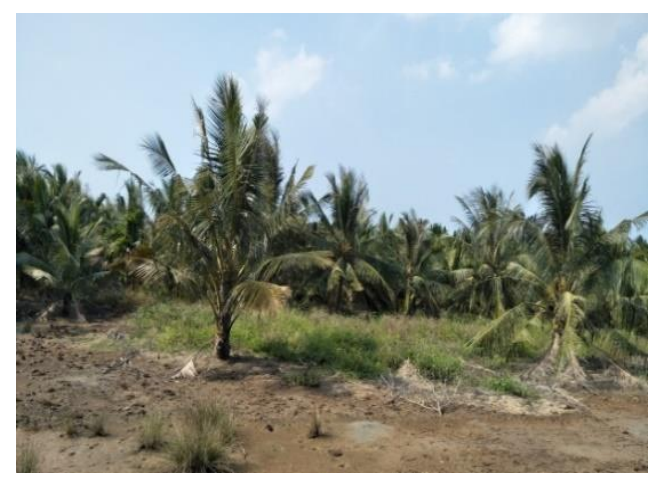

(a)

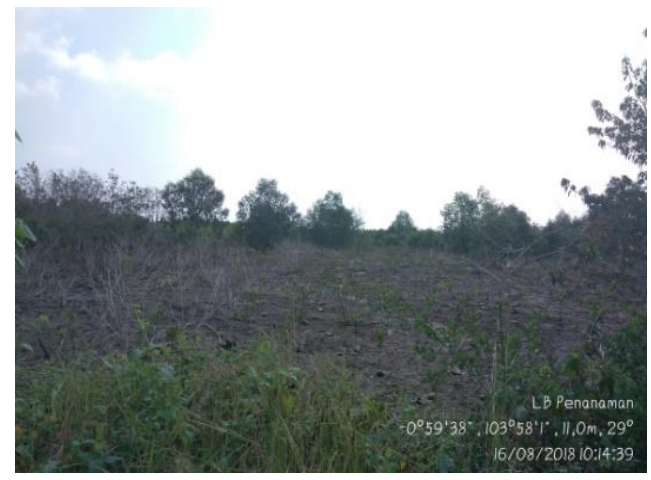

(c)

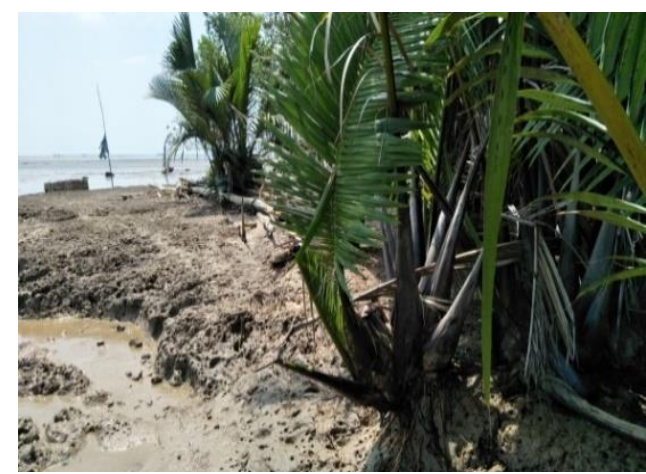

(b)

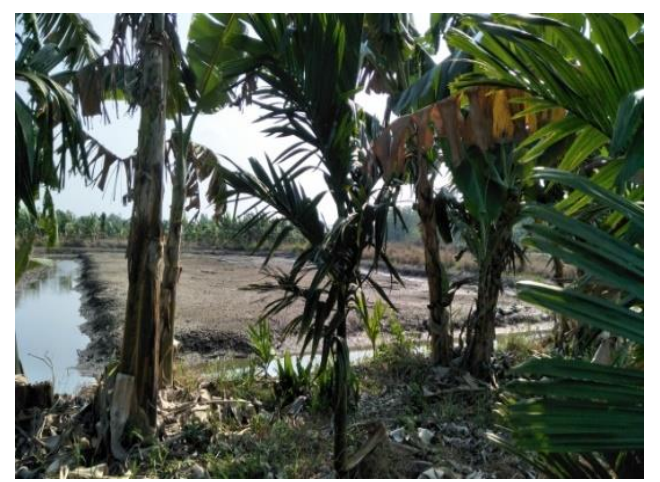

(d)

Gambar 4 Keadaan hutan mangrove di Desa Lambur

(a) perkebunan kelapa dibelakang hutan mangrove yang telah mengalami abrasi (b) nipah yang berada pada zonasi terdepan (c) area bekas tambak (d) lokasi penanaman.

Untuk kegiatan analisis vegetasi, lokasi yang dipilih yaitu yang bisa mewakili hasil interpretasi citra atau perhitungan NDVI dan kondisinya di lapangan. Dari analisis vegetasi ini diperoleh nilai rata-rata kerapatan mangrove termasuk kategori kerapatan sedang dengan 1385 individu/ha. Sebagian besar hutan mangrove di Desa Lambur didominasi oleh spesies Buta-buta (Excoecaria agallocha) dan Api-api Hitam (Avicennia officinalis). Formasi untuk hutan mangrove ini sudah tidak sesuai dengan keadaan seharusnya, dimana pada setiap bagian mangrove baik dari arah pantai ke arah darat telah ditumbuhi Nipah yang menjadi spesies yang berada paling belakang. Letak Api-api dan Bakau pun saling berdampingan, dimana seharusnya posisinya adalah Api-Api terletak dibagian depan formasi yang berbatasan dengan pantai dan Bakau dibelakang formasi Api-api. Keadaan formasi Hutan Mangrove Lambur dapat dilihat pada Gambar 5.

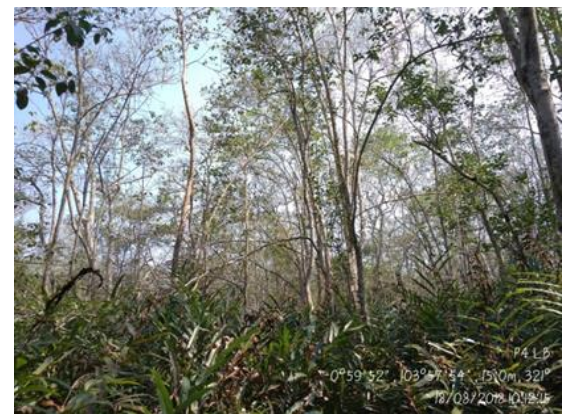

(a)

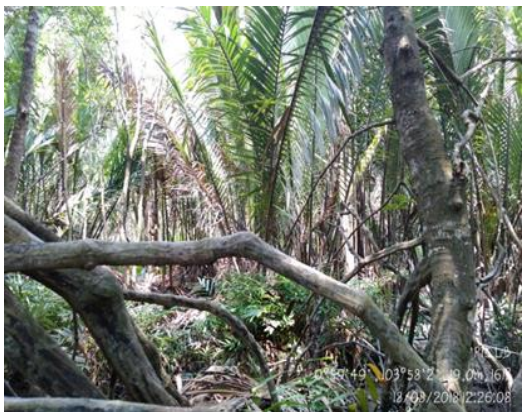

(b)

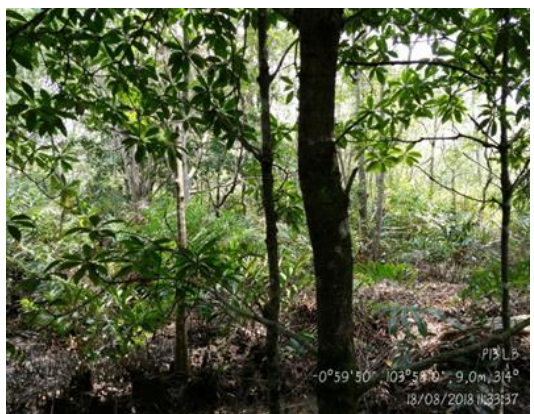

(c)

Gambar 5 Formasi Hutan Mangrove Lambur (a) Buta-Buta (c) Nipah (d) Api-api Hitam 
Tabel 6 Jenis-jenis yang ditemukan di plot pengamatan lambur

\begin{tabular}{ccc}
\hline No & Nama Lokal & Nama Latin \\
\hline 1 & Tancang & Bruguiera sexangula \\
2 & Buta-buta & Excoecaria agallocha \\
3 & Api-api hitam & Avicennia officinalis \\
4 & Api-api kuning & Avicennia alba \\
5 & Bakau putih & Rhizophora apiculata \\
\hline
\end{tabular}

Titik ground check terakhir berada di Mendahara Ilir. Ada perbedaan data hasil interpretasi citra dengan data analisis vegetasi, dimana data interpretasi citra menunjukkan bahwa lokasi ini termasuk kategori mangrove kerapatan tinggi, namun saat dilakukan analisis vegetasi hasilnya menunjukan mangrove ini termasuk kategori jarang. Hasil dari analisis vegetasi menunjukan bahwa jumlah individu pohonnya adalah 740 individu/ha yang masuk dalam kategori jarang.

Perbedaan hasil intepretasi dan analisis vegetasi ini disebabkan karena individu yang terdapat di dalam plot merupakan individu (tumbuhan mangrove) yang berada pada stadia pohon yang memiliki diameter yang besar (lebih dari $20 \mathrm{~cm}$ ) dan keberadaan Nipah yang memiliki tajuk yang lebar (Gambar 6). Hal ini membuat jumlah individu di dalam plot sedikit akan tetapi tutupan tajuk dari tumbuhan tersebut terbilang besar sehingga nilai tangkapan dari citra satelit/nilai NDVI tutupan lahan tersebut tergolong pada tingkatan tutupan yang Rapat.

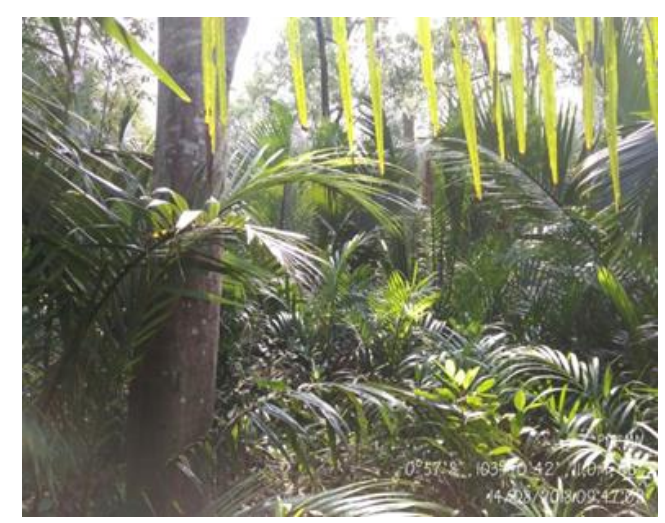

(a)

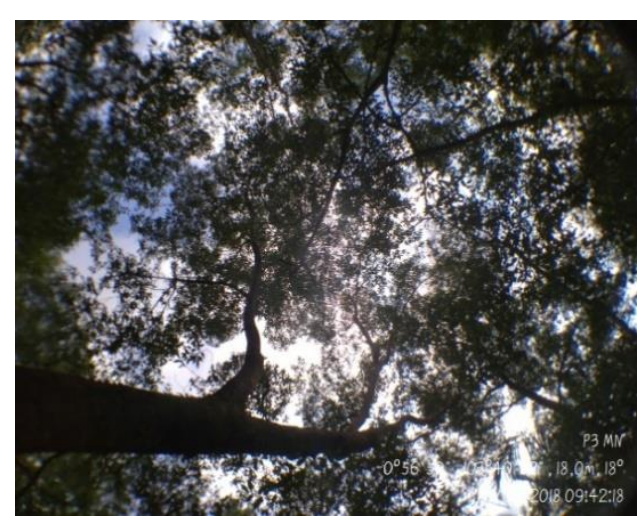

(b)

Gambar 6 Keadaan Hutan Mangrove Mendahara Ilir (a) pohon besar yang dikelilingi Nipah (b) tutupan tajuk pohon-pohon berdiameter besar.

Formasi di Hutan Mangrove Mendahara Ilir ini sudah mulai terganggu, dimana Nipah yang seharusnya berada di posisi belakang terdapat di rata-rata seluruh bagian mangrove baik dari bagian depan (Api-api), tengah (Bakau) dan belakang.

Tabel 7 Nama spesies yang ditemukan di plot pengamatan mendahara ilir

\begin{tabular}{ccc}
\hline No & Nama Lokal & Nama Latin \\
\hline 1 & Bakau putih & Rhizophora apiculata \\
2 & Api-api hitam & Avicennia officinalis \\
3 & Perepat & Sonneratia alba \\
4 & Api-api kuning & Avicennia alba \\
5 & Pisang-pisang & Kandelia candel \\
\hline
\end{tabular}




\section{Perubahan Garis Pantai}

Analisis perubahan garis pantai sepanjang pesisir Provinsi Jambi dilakukan dengan tumpang susun (overlay) garis pantai hasil interpretasi Citra Landsat TM tahun 1989, 2000 serta peta garis pantai hasil interpretasi Citra Landsat 8 tahun 2018 (Gambar 7). Dari hasil overlay terlihat bahwa garis pantai yang berada di Kecamatan Sebrang Kota, Tungkal Ilir (Kuala Tungkal), Kuala Betara (Betara Kiri), Mendahara (Pangkal Duri dan Mendahara Ilir), Kuala Jambi (Lagan Ilir), Nipah Panjang (Pemusiran) dan Sadu (Sungai Lokan, Sungai Sayang dan Remaubakutuo) mengalami perubahan yaitu penambahan daratan (akresi). Sebalikanya pada daerah Kecamatan Muara Sabak Timur (Lambur, Sungai Ular, Simbur Naik), Nipah Panjang (Nipah Panjang) dan Sadu (Sungai Lokan, Air Hitam, Sungai Cemara, Labuan Paning dan Sungai Benuh) mengalami pengurangan daratan (Abrasi).

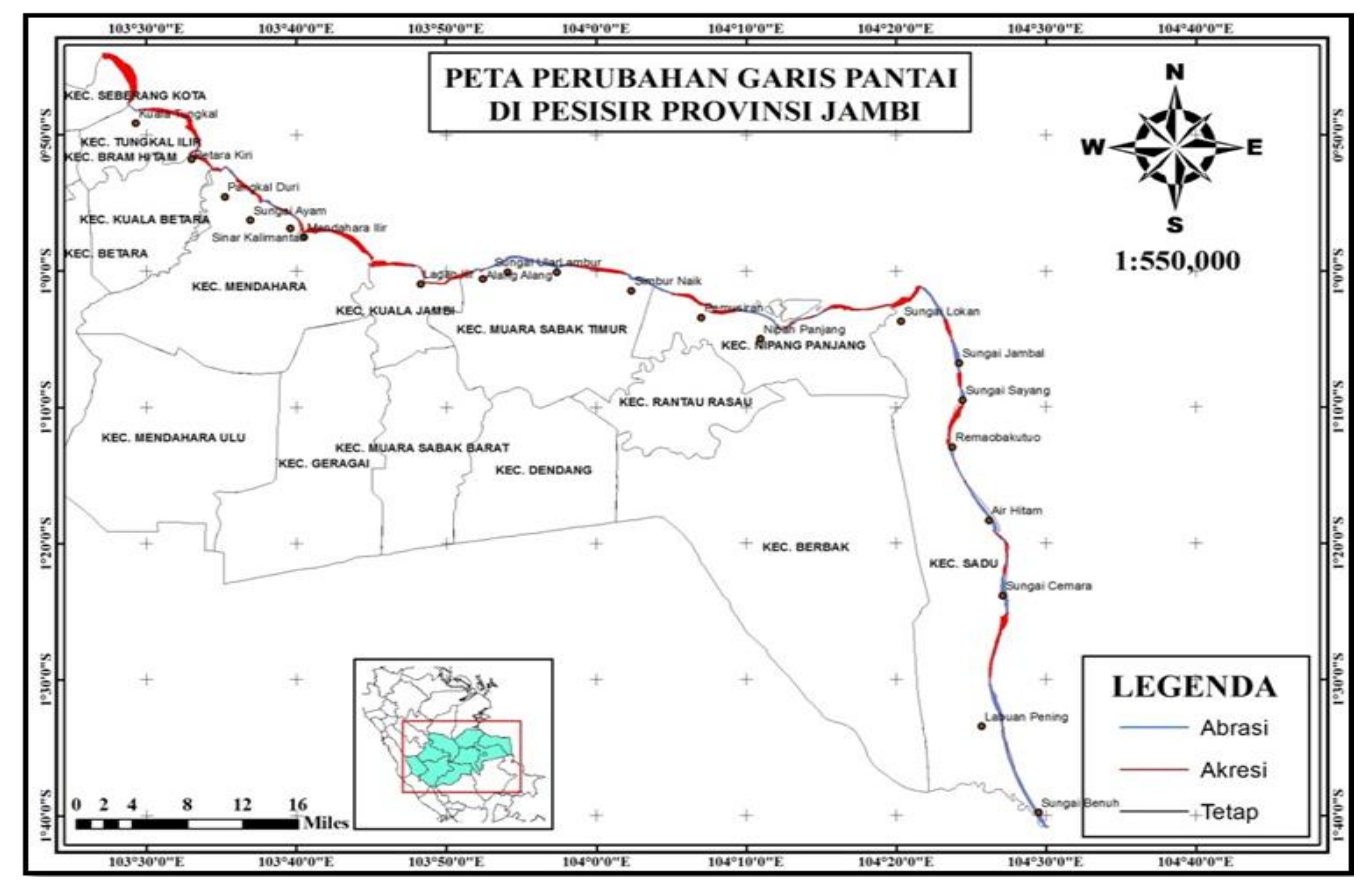

Gambar 7 Peta perubahan garis pantai di pesisir Provinsi Jambi.

Hasil pengelolaan perubahan garis pantai menggunakan Digital Shoreline Analisis System (DSAS) didapat transek yang berjumlah 7127, dimana setiap transek memiliki jarak $30 \mathrm{~m}$. Transek ini terbagi di beberapa Kecamatan, dimana untuk Kabupaten Tanjung Jabung Barat transek terbagi di Kecamatan Kota Sebrang, Tungkal Ilir dan Kuala Betara yang berada di transek 1-862. Sedangkan untuk Kabupaten Tanjung Jabung Timur terbagi beberapa Kecamatan yang langsung berbatasan dengan wilayah pesisir yaitu Mendahara berada di transek 579-1755, Kuala Jambi 1805-2237, Sabak Timur 2238-3116, Nipah Panjang 3117-4240 dan Sadu 4280-7127 (Gambar 8). 


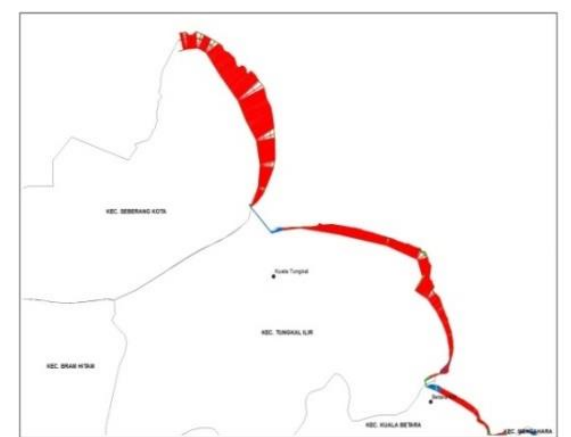

a. 1-862

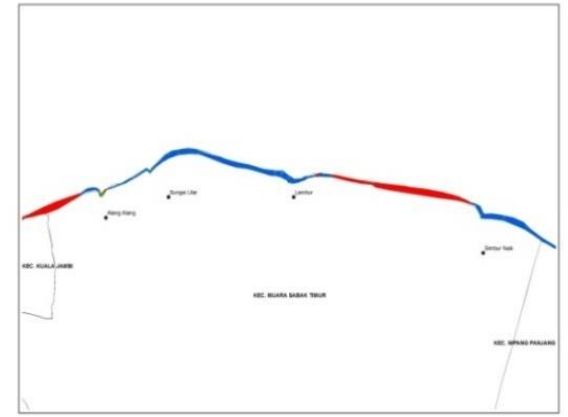

d. $2238-3116$

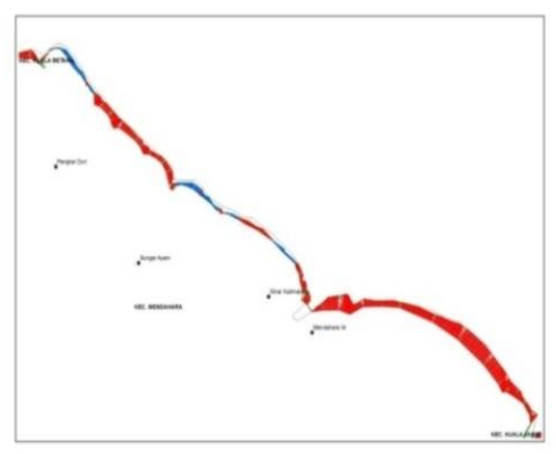

b. $863-1755$

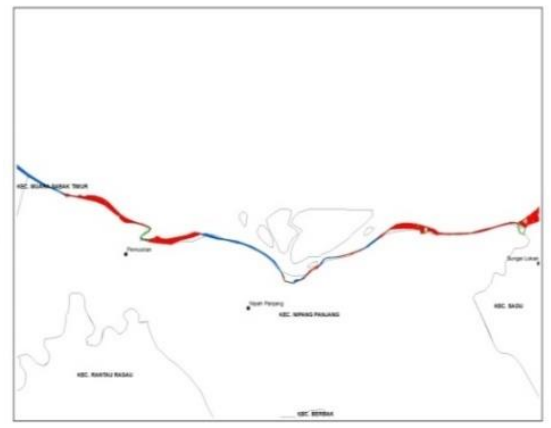

e. $3117-4240$

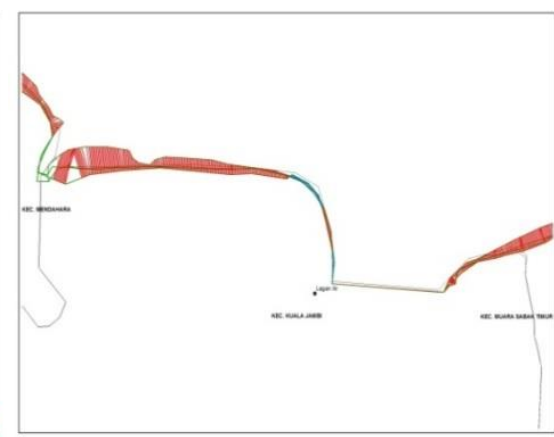

c. $1805-2237$

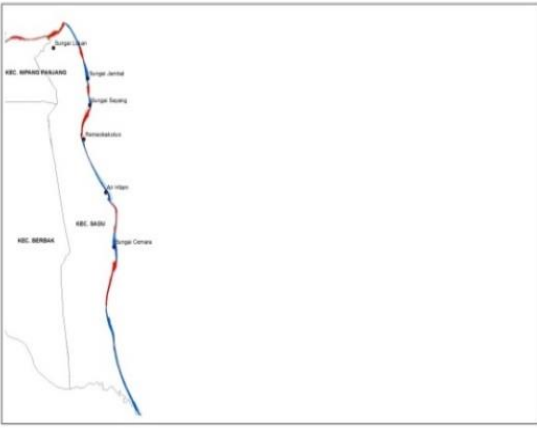

f. $4280-7127$

Gambar 8 Pembagian transek berdasarkan kecamatan (a) Kota Sebrang, Tungkal Ilir dan Kuala Betara (b) Mendahara (c) Kuala Jambi (d) Sabak Timur (e) Nipah Panjang (f) Sadu.

\section{Hubungan Kerapatan dan Perubahan Garis Pantai}

Berdasarkan hasil kerapatan dan perubahan garis pantai yang telah didapatkan, secara kualitatif (deskriptif) terlihat bahwa hubungan keduanya adalah saling berkaitan. Dimana, jika tutupannya rapat dan sedang maka garis pantainya akan mengalami penambahan (akresi) dan jika kerapatannya rendah maka akan mengalami pengurangan (abrasi). Hal ini sesuai dengan Bengen (2001) yang menjelaskan bahwa salah satu pertahanan terbaik untuk menjaga suatu kawasan dari proses abrasi adalah hutan mangrove dan Kumara et al. (2010) yang menjelaskan bahwa kerapatan mangrove berkontribusi terhadap tingkat luasan akresi, distribusi sedimen dan tinggi elevasi permukaan.

Lokasi yang mengalami akresi (penambahan daratan) yaitu Kecamatan Kota Sebrang, Tungkal Ilir, Kuala Betara, Mendahara, Kuala Jambi dan Nipah Panjang, dapat dilihat bahwa perubahan tutupan mangrovenya dari tahun 1989, 2000 dan 2018 didominasi masih dalam keadaan rapat dan sedang. Meskipun ada beberapa bagian yang terinterpretasikan memiliki tutupan jarang, hanya saja tidak terlalu signifikan dan hanya di bagian tepi pantai yang menunjukkan daratan itu baru terbentuk dan belum banyak spesies mangrove yang tumbuh.

Lokasi yang mengalami abrasi (pengurangan daratan) yaitu Kecamatan Sabak Timur dan Sadu, dapat dilihat bahwa dari tahun ke tahun tutupan mangrove yang kondisi kerapatan awalnya rapat semakin lama semakin sedang dan menjadi kerapatan jarang. Pada tahun 1989 warna tutupannya menunjukkan warna hijau yang berarti bahwa lokasi itu memiliki kerapatan mangrove yang tinggi, kemudian menurun di tahun 20002018. Pada tahun 2018, baik di Sabak Timur maupun di Sadu memiliki tutupan kategori kerapatan jarang dengan luas yang cukup besar dibandingkan Kecamatan lainnya, hal ini yang menyebabkan terjadinya pengurangan daratan (abrasi) di wilayah tersebut. Kejadian abrasi di pesisir Provinsi Jambi ini juga hampir tidak berbeda dengan abrasi yang terjadi di pesisir Kabupaten Bekasi yang juga mengalami kerusakan atau rendahnya kerapatan vegetasi hutan mangrove yaitu sekitar 35 meter (Putra et al., 2016). 
Tabel 9 Hasil perubahan dan kerapatan garis pantai

\begin{tabular}{|c|c|c|c|c|c|c|}
\hline \multirow{2}{*}{ No } & \multirow{2}{*}{ Kecamatan } & \multirow{2}{*}{ Tahun } & \multicolumn{3}{|c|}{ Luas (ha) } & \multirow{2}{*}{ Garis Pantai } \\
\hline & & & Jarang & Sedang & Rapat & \\
\hline \multirow{3}{*}{1} & \multirow{3}{*}{ Kota Sebrang } & 2018 & 46.38 & 643.04 & 175.28 & \multirow{3}{*}{ Akresi } \\
\hline & & 2000 & 19.99 & 31.05 & 425.8 & \\
\hline & & 1989 & 13.26 & 10.92 & 385.66 & \\
\hline \multirow{3}{*}{2} & \multirow{4}{*}{ Tungkal Ilir } & 2018 & 44.30 & 492.62 & 92.75 & \multirow{3}{*}{ Akresi } \\
\hline & & 2000 & 79.73 & 52.94 & 265.76 & \\
\hline & & 1989 & 24.36 & 15.28 & 484.25 & \\
\hline \multirow{4}{*}{3} & & 2018 & 15.18 & 151.16 & 57.51 & \multirow{4}{*}{ Akresi } \\
\hline & \multirow[t]{3}{*}{ Kuala Betara } & 2000 & 21.50 & 16.12 & 167.72 & \\
\hline & & 1989 & 14.57 & 6.47 & 420.84 & \\
\hline & & 2018 & 47.61 & 917.82 & 638.91 & \\
\hline \multirow[t]{3}{*}{4} & \multirow[t]{3}{*}{ Mendahara } & 2000 & 105.09 & 174.17 & 873.15 & \multirow[t]{3}{*}{ Akresi } \\
\hline & & 1989 & 34.12 & 45.19 & 1208.44 & \\
\hline & & 2018 & 35.72 & 397.50 & 330.99 & \\
\hline \multirow[t]{3}{*}{5} & \multirow[t]{3}{*}{ Kuala Jambi } & 2000 & 77.20 & 73.08 & 215.53 & \multirow[t]{3}{*}{ Akresi } \\
\hline & & 1989 & 43.75 & 46.60 & 426.08 & \\
\hline & & 2018 & 191.93 & 1178.87 & 649.49 & \\
\hline \multirow[t]{3}{*}{6} & \multirow[t]{3}{*}{ Sabak Timur } & 2000 & 62.88 & 89.16 & 744.83 & \multirow[t]{3}{*}{ Abrasi } \\
\hline & & 1989 & 40.19 & 42.58 & 1542.02 & \\
\hline & & 2018 & 123.62 & 499.49 & 186.79 & \\
\hline \multirow[t]{3}{*}{7} & \multirow[t]{3}{*}{ Nipah Panjang } & 2000 & 125.06 & 137.73 & 419.13 & \multirow[t]{3}{*}{ Akresi } \\
\hline & & 1989 & 38.92 & 67.51 & 1078.22 & \\
\hline & & 2018 & 469.19 & 1015.03 & 944.72 & \\
\hline \multirow[t]{2}{*}{8} & Sadu & 2000 & 126.33 & 106.44 & 1114.28 & \multirow[t]{2}{*}{ Abrasi } \\
\hline & & 1989 & 90.96 & 74.40 & 1605.8 & \\
\hline
\end{tabular}

Penurunan luas tutupan mangrove bukanlah satu-satunya faktor yang mempengaruhi perubahan garis pantai. Perubahan garis pantai secara alami dapat disebabkan oleh gelombang, arus, angin, sedimentasi, dan pasang surut (Ongkosongo, 1989), sedangkan faktor manusia seperti kegiatan pembukaan lahan, eksploitasi bahan galian, dan reklamasi pantai (Tarigan, 2007). Menurut Kusmana (2015), tingkat gangguan dan variasi pengaruh yang disebabkan oleh manusia pada ekosistem mangrove telah meningkat secara konstan, sehingga sebagian besar mangrove dunia terancam rusak.

\section{KESIMPULAN}

Perubahan kerapatan tutupan mangrove yang terjadi dalam kurun waktu 1989-2018 menyebabkan perubahan garis pantai. Perubahan garis pantai ini merupakan hasil dari proses abrasi dari beberapa kerapatan mangrove yang telah jarang dan sebaliknya mengalami akresi ditutupan mangrove yang rapat dan sedang. Kerapatan tutupan mangrove dari tahun 1989-2018 cenderung menurun dimana untuk kerapatan tinggi berturut-turut dari tahun 1989, 2000 dan 2018 yaitu 7442.39 ha berkurang menjadi 4659.75 ha dan 3275.079 ha. Untuk tutupan sedang dan jarang cenderung meningkat, dimana tutupan sedang meningkat dari 369.621 ha menjadi 769.604 ha dan 5766.92 ha sedangkan tutupan jarang meningkat dari 441.361 ha mejadi 747.524 ha dan 1155.83 ha.

Akresi terjadi di empat lokasi yang memiliki tutupan kerapatan sedang dan rapat dengan rata-rata perubahannya yaitu Kota Sebrang 771 m, Tungkal Ilir 240.65 m, Kuala Betara 153.73 m, Mendahara 167.78 m, Kuala Jambi 167.78 m dan Nipah Panjang 57.3 m, sedangkan abrasi terjadi di dua lokasi dengan tutupan kerapatan jarang yang cukup luas dengan rata-rata perubahan yaitu di Sabak Timur -41.8 m dan Sadu -36.55 m. 


\section{UCAPAN TERIMA KASIH}

Ucapan terima kasih disampaikan kepada Fakultas Kehutanan dan LPPM Universitas Jambi atas dukungan dana penelitian skim penelitian dosen senior PNBP Fakultas Kehutanan, tim penelitian baik dosen, mahasiswa dan tenaga lapangan yang telah berkontribusi dalam kelancaran penelitian ini

\section{DAFTAR PUSTAKA}

Ajithkumar TT, Thangaradjou T, Kannan L. 2008. Spectral reflectance properties of mangrove species of the muthupettai mangrove environment, Tamil Nadu. Journal of Environmental Biology. 29(5): 785-788.

Bengen DG. 2001. Prosiding Pelatihan Pengelolaan Wilayah Pesisir Terpadu. Bogor (ID): Pusat Kajian Sumberdaya Pesisir dan Lautan.

Balai Konservasi Sumber Daya Alam Jambi. 2011. Rencana Pengelolaan Cagar Alam Hutan Bakau Pantai Timur Jambi. Jambi (ID): Balai Konservasi Sumber Daya Alam Jambi.

Departemen Kehutanan. 2005. Pedoman Inventarisasi dan Identifikasi Lahan Kritis Mangrove. Jakarta (ID): Direktorat Jenderal Rehabilitasi Lahan dan Perhutanan Sosial Departemen Kehutanan

Istiqomah F, Sasmito B, Amarrohman FJ. 2016. Pemantauan perubahan garis pantai menggunakan Aplikasi Digital Shoreline Anaysis System (DSAS) Studi kasus: Pesisir Kabupaten Demak. Jurnal Geodesi Undip. 5(1): 78-89.

Kasim F. 2012. Pendekatan beberapa metode dalam monitoring perubahan garis pantai menggunakan Dataset Penginderaan Jauh Landsat dan SIG. Jurnal Ilmiah Agropolitan. 5(1): 620-635.

Kumara MP, Jayatissa LP, Krauss KW, Phillips DH, Huxam M. 2010. High mangrove density enhances surface accretion, surface elevation change, and tree survival in coastal areas susceptible to sea-level rise. Oecologia. 164(2): 545-553.

Kusmana C. 2009. Pengelolaan sistem mangrove secara terpadu. Workshop Pengelolaan Ekosistem Mangrove di Jawa Barat, Jatinangor 18 Agustus 2009. 1-22.

Kusmana C. 2015. Integrated sustainable mangrove forest management. Jurnal Pengelolaan Sumberdaya Alam dan Lingkungan. 5(1): 1-6.

Limber PW, List JH, Warren JD. 2007. Investigating Methods of Mean High WaterShoreline Extraction from Lidar Data and the Relationship between Photoderived and Datum-based Shorelines in North Carolina [Internet]. Tersedia pada: http://ims.ncdenr.org/Website/ncshore/MetaData/2004_Shoreline_Study.pdf.

Lubis DP, Pinem M, Simanjuntak MAN. 2017. Analisis perubahan garis pantai dengan menggunakan citra penginderaan jauh. Jurnal Geografi. 9(1): 21-31.

Ongkosongo OSR. 1989. Penerapan Pengetahuan dan Data Pasang-Surut Dalam Pasang-Surut. Jakarta (ID): Pusat Penelitian dan Pengembangan Oseanologi-LIPI.

Onrizal. 2008. Panduan Pengenalan dan Analisis Vegetasi Hutan Mangrove. Medan (ID): Universitas Sumatera Utara.

Parman S. 2010. Deteksi perubahan garis pantai melalui citra penginderaan jauh di pantai utara Semarang Demak. Jurnal Geografi. (7)1: 30-38.

Pemerintah Provinsi Jambi. 2015. Laporan Status Lingkungan Hidup Daerah Provinsi Jambi. Jambi (ID): Pemerintah Provinsi Jambi.

Putra H, Prasetyo LB, Santoso N. 2016. Monitoring perubahan garis pantai dengan citra satelit di Muara Gembong Bekasi. Jurnal Pengelolaan Sumberdaya Alam dan Lingkungan. 6(2): 178-186.

Rouse JW, Haas RH, Schell JA, Deering DW. 1973. Monitoring vegetation systems in the Great Plains with ERTS [Internet]. Tersedia pada: https://ntrs.nasa.gov/archive/nasa/casi.ntrs.nasa.gov/19740022614.pdf.

Sugiyono. 2005. Memahami Penelitian Kualitatif. Bandung (ID): Alfabeta. 
Tarigan MS. 2007. Perubahan garis pantai di wilayah pesisir perairan Cisadane, Provinsi Banten. Makara, Sains. 11(1): 49-55.

Thieler ER, Himmelstoss EA, Zichichi JL, Ergul, Ayhan. 2009. Digital Shoreline Analysis System (DSAS) version 4.0-An ArcGIS extension for calculating shoreline change. U.S. Geological Survey Open-File Report 2008-1278.

van Heuvel Tj, Hillen R. 1994. Coastline management with GIS in the Netherlands. In: EARSeL. Workshop on Remote Sensing and GIS for Coastal Zone Management. 155-164.

Winarso GJ, Budhiman S. 2001. The potential application remote sensing data for coastal study. [Paper] presented at the 22nd Asian conference on remote sensing, 5-9 November 2001, Singapore. Centre for remote imaging, sensing and processing (CRISP), National University of Singapore; Singapore Institute of Surveyors and Valuers (SISV); Asian Association on Remote Sensing (AARS). 